\title{
MAPPING OF ENVIRONMENTAL SENSITIVITY INDEX TO OIL SPILL FROM LANDSAT TM IMAGES: "A STUDY CASE ON THE AMAZON COASTAL PLAIN"
}

\author{
Recebido em 6 dezembro, 2011 / Aceito em 16 agosto, 2012 \\ Received on December 6, 2011 / Accepted on August 16, 2012
}

Suzan Waleska Pequeno Rodrigues ${ }^{1}$ and Pedro Walfir M. Souza-Filho ${ }^{1,2}$

\begin{abstract}
The environmental sensitivity index (ESI) is represented by a scale ranging from 1 to 10 , where the intensity of the impact caused by the oil spill is specified and, the higher the value the higher the sensitivity index. Oil spills impact the environment and are not exclusive to certain regions of the world. Therefore, the production of maps representing the ESI has become important for the implementation of contingency and emergency plans. Curuçá city, located in northeastern Pará state, does not have a map of semi-detailed environmental sensitivity, for that reason, this study aimed to generate a tactical map, scale of 1:100,000, with recognition of coastal environments identified by digital processing of Landsat images and field surveys. The map will help identify the areas more prone to suffer from a possible oil spill. Thus, eight indices were classified as follows: ESI 1B retaining wall, ESI 1C cliffs, ESI 3A sandy beaches and exposed dunes, ESI 7 sandy tidal flat, ESI 9 ebb tide delta, ESI 10A salt marsh, ESI 10B freshwater marsh and ESI 10 mangrove. Finally, the ESI represented in these maps can support the decision making process to prevent and control accidents that may happen during oil production and transportation. Benefits may reflect on lower costs of cleaning and restoration of the impacted areas in case of oil and other potentially harmful load spills.
\end{abstract}

Keywords: environmental sensitivity index, remote sensing, coastal environment.

RESUMO. 0 índice de sensibilidade ambiental (ISA) é representado por números que variam de 1 a 10, especificando a escala de impacto causado pelo óleo, quanto maior for 0 seu valor, maior é o índice de sensibilidade. 0 derramamento de óleo já não é mais um fato isolado e esporádico no mundo, causando inúmeros impactos ambientais, portanto, a produção de mapas que representam o ISA tornou-se importante para a implementação de planos de contingência e de emergência. 0 município de Curuçá, região nordeste do estado do Pará, não possui um mapa de semi-detalhe, assim, este trabalho teve como objetivo a construção de um mapa tático na escala de 1:100.000 e o reconhecimento dos ambientes costeiros através do processamento de imagens Landsat e do levantamento de campo contribuindo para a identificação das áreas que mais sofrerão com um eventual derramamento de óleo. Deste modo foi possível classificar oito índices: ISA 1B muro de arrimo, ISA 1C falésias, ISA 3A praias de areia fina e dunas expostas, ISA 7 planície de maré arenosa, ISA 9 delta de maré vazante, ISA 10A pântano salino; ISA 10B pântano de água doce e ISA 10C manguezal. Assim, os ISA's são produtos que representados em mapa podem ajudar na tomada decisões na prevenção e no controle de acidentes durante as atividades de produção e no transporte do óleo usado pelas companhias produtoras, tornando-se uma boa estratégia de prevenção, a qual pode evitar os altos custos das operações de limpeza e recuperação de ambientes impactados no caso de derramamentos de óleo e cargas de risco.

Palavras-chave: índice de sensibilidade ambiental, sensoriamento remoto, ambientes costeiros.

\footnotetext{
1 Universidade Federal do Pará, Instituto de Geociências, Laboratório de Análise de Imagens do Trópico Úmido - LAIT, Av. Augusto Correa, 1, Campus do Guamá, P.0. Box 8608, 66075-110 Belém, PA, Brazil. Phone: +55(91) 3201-8009; Fax: +55(91) 3183-1478 - E-mails: suzan@ufpa.br, walfir@ufpa.br

2 Instituto Tecnológico Vale, Desenvolvimento Sustentável, Travessa Dr. Moraes, 78, 66035-080 Belém, PA, Brazil - E-mail: walfir@ufpa.br
} 


\section{INTRODUCTION}

In the mid-70s the US started to develop contingency plans that included the recognition and mapping of the areas sensitive to oil spills, based solely on their geomorphological characteristics (Hayes \& Gundlach, 1975). The authors Gundlach \& Hayes (1978) associated the biological with the geomorphological characteristics and created the first sensitivity index to oil spills. From then on, sensitivity maps have evolved and were adopted in several countries, among them, Australia (Thompson \& McEnally, 1985), Svalbart Island (Moe et al., 2000) and Brazil (Wieczorek et al., 2007; Souza Filho et al., 2009a).

In March 2002, the standards and specifications for the Environmental Sensitivity Index (MMA, 2004) were referenced by the Cartography National Commission (Comissão Nacional de Cartografia, COMCAR), so that the Charts of Environmental Sensitivity to Oil Spills (Cartas SAO) are now considered cartographic documents by the Brazilian government. They are essential to develop contingency plans to manage spills of oil and its derivatives, contributing to the localization and mapping of high risk areas.

The environmental sensitivity index (ESI) also known as coastal sensitivity index (CSI) ranges from 1 to 10 , representing the scale of the impact caused by the oil (NOAA, 2002; MMA, 2004). The ESI grading system is characterized by the following factors: type of substrate; relative exposure to waves and tidal energy; biological productivity and sensitivity; slope of the coast, and easiness of cleaning (Halls et al., 1997). In recent years, Petrobras (2002) and Souza Filho et al. (2009b) made adjustments to the ESI charts of the Amazonian coastal areas.

In Brazil, the environmental sensitivity index has been used to support the measures taken to prevent and contain eventual oil spills on the coast. An important tool that helps to produce the ESI charts is remote sensing which, through satellite data processing makes the research fast, accessible and effective.

Works on this subject have already been published for the Southern (Santos \& Griep, 2007; Bellotto \& Sarolli, 2008; Noernberg et al., 2008), Southeastern (Carmona et al., 2006; Gherardi et al., 2008) and Northeastern (Castro et al., 2003; Alcântara \& Santos, 2005; Carvalho \& Gherardi, 2008) regions. Despite having no oil platform installed in the northern region, the risk of accidents is due to the transportation of oil and its derivatives along the coast and Rivers Amazonas, Solimoes and its tributaries. Thus, studies about the ESI have been published for this region, among them we highlight Almeida (2009); Gonçalves et al. (2009); Boulhosa \& Souza Filho (2009); Rodrigues \& Souza Filho (2011).
Landsat TM images of the studied area are going to be used to produce a chart of the sensitivity environmental index to oil spills in a Marine Extractive Reserve, located in the city of Curuçá, in order to support preventive measures against a possible oil spill in the area. Thus, the coastal environments are mapped based on the classification and interpretation of the images from the Landsat-5 Thematic Mapper - TM and field work to produce an ESI chart adapted to the Amazon coastal area (Souza Filho et al., 2009b) in tactical scale $(1: 100,000)$.

\section{STUDY SITE}

The study site is part of the Mãe Grande de Curuçá Extractive Reserve that covers an area of 37,062 hectares on the northeastern coast of Pará state (Fig. 1). This area is dominated by semidiurnal macro-tides, with $4 \mathrm{~m}$ maximum height. The waves hit this area with approximate average height of $2 \mathrm{~m}$, while the NE trade winds reach average speed of $6.6 \mathrm{~m} / \mathrm{s}$ (CPTEC/INPE, 2005). The climate is rainy tropical (humid), with well-defined dry and rainy seasons and annual rainfall of about 3,000 $\mathrm{mm}$. According to El Robrini \& Mácola (2004) the islands are held by sediments from the Grupo Barreiras formation. Geomorphologically, the area is compartmentalized into: (1) Coastal Plateau/Plain dominated by features of hilly relief of irregular shapes with small amplitudes, occurs especially on the Island of Mutucal (mostly on the flooded northern edge), Island of Ipomonga (exclusively on the southeast) and Island of Guarás/Marinteua and Romana (where it is buried); and (2) Fluviomarine Plain - consists of relatively flat terrain, discontinuous on the shoreline. This regional geomorphological unit is compartmentalized into three sub-units or environments: (i) flood plain; (ii) estuarine plain with canal, subdivided into upper course straight segment, meandering segment and estuarine funnel, and (iii) coastal plain, environments of supra-tidal plain, tidal flat (supra-tidal, inter-tidal and sub-tidal mangroves, sandy plain, barrier-beach ridge, active and inactive coastal dunes, emerged bars, with low tide).

\section{MATERIALS AND METHODS}

\section{Materials}

The characteristics of Landsat- 5 Thematic Mapper - TM images used in this study are shown in Table 1. The images were acquired from the catalog of the National Institute for Space Research (Instituto Nacional de Pesquisas Espaciais, INPE http://www.dgi.inpe.br/CDSR/). The Landsat-7 Enhanced Thematic Mapper plus - ETM ${ }^{+}$image was acquired from the site GeoCover (http://glcfapp.umiacs.umd.edu:8080/esdi/index.jsp), 


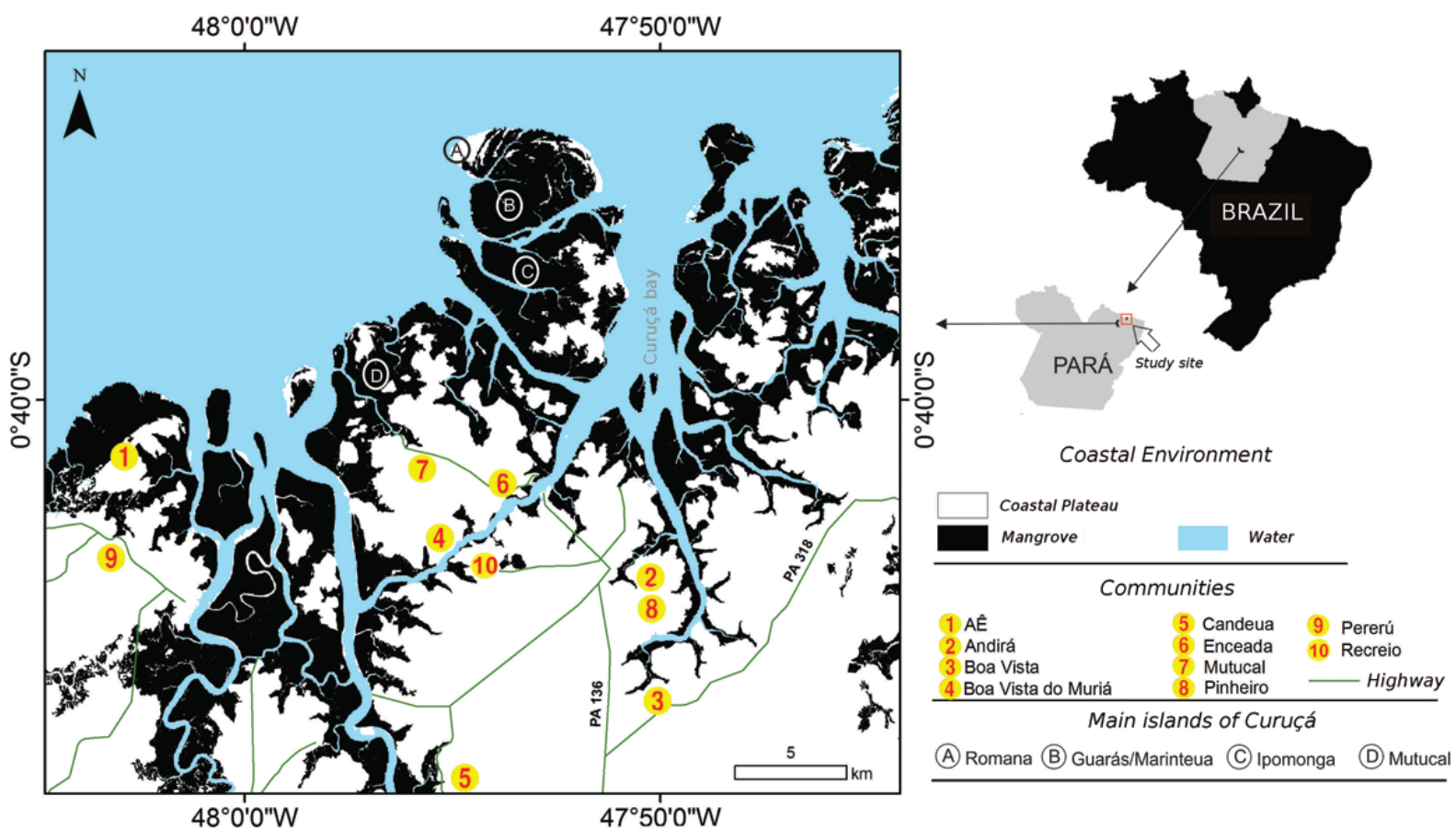

Figure 1 - Map showing the location and boundaries of the mangrove and the main islands along the study site.

Table 1 - General characteristics of the images used.

\begin{tabular}{|c|c|c|c|c|c|}
\hline Platform & Sensor & $\begin{array}{c}\text { Acquisition } \\
\text { date }\end{array}$ & $\begin{array}{c}\text { Incidence } \\
\text { angle }\end{array}$ & $\begin{array}{c}\text { Spatial } \\
\text { resolution }(\mathrm{m})\end{array}$ & Tide \\
\hline Landsat-5 & TM & $09 / 07 / 2008$ & Nadir & 30 & high \\
Landsat-7 & ETM $^{+}$ & $05 / 08 / 2001$ & Nadir & 30 -mult./15-Pan & high \\
SRTM v4 & InSAR & Set. 2008 & Off-nadir & 90 & - \\
\hline
\end{tabular}

and the Digital Elevation Model (DEM) of the Shuttle Radar Topography Mission (SRTM) was acquired from the Consortium for Spatial Information (CGIAR-CSI - http://srtm.csi.cgiar.org/).

\section{Digital data processing}

The flowchart in Figure 2 shows the procedure followed to preprocess and process the images from the Landsat- 5 TM. Initially, atmospheric correction was performed in the visible and infrared bands by subtracting dark pixels following the methodology proposed by Chavez Jr. (1996). Subsequently, the images were enhanced by the linear transformation of the Look up table (LUT) of the Algorithm Librarian in the software PCI Geomatics 10.3 (PCl, 2010).

The mosaic images, together with the DEM of the SRTM, were orthorectified based on the Lansat-7 ETM ${ }^{+}$images, using the OrthoEngine tool. Orthorectification was based on the data point collection from the Landsat-7 ETM ${ }^{+}$images. The resampling method used was the nearest neighbor, where 30 control points with root mean square (RMS) of 0.06 pixels were collected.

Orthorectification was validated by the Cartographic Accuracy Standards (CAS) and Standard Error (SE) which classify the generated map (Table 2) according to trend and precision analysis. Means were analyzed using t-test and Chi-square test $\left(\chi^{2}\right)$ to verify, respectively, if mean of the discrepancies is zero and if sampling variance from the standard error is the same, indicating precision. The equations used to calculate positional accuracy according to Camargo et al. (2007) are shown in Table 3. Planialtimetric validation was calculated using 10 ground control points with RMS of 0.40 pixels for the orthorectified images. Check points were collected in the field using the GPS Garmin 72 with WAAS Receptor (5m precision). Accuracy analysis was performed for a scale of $1: 100,000$, for $t_{39 ; 0,05}$ and $\chi_{39,10 \%}^{2}$, for a total of 40 samples. 


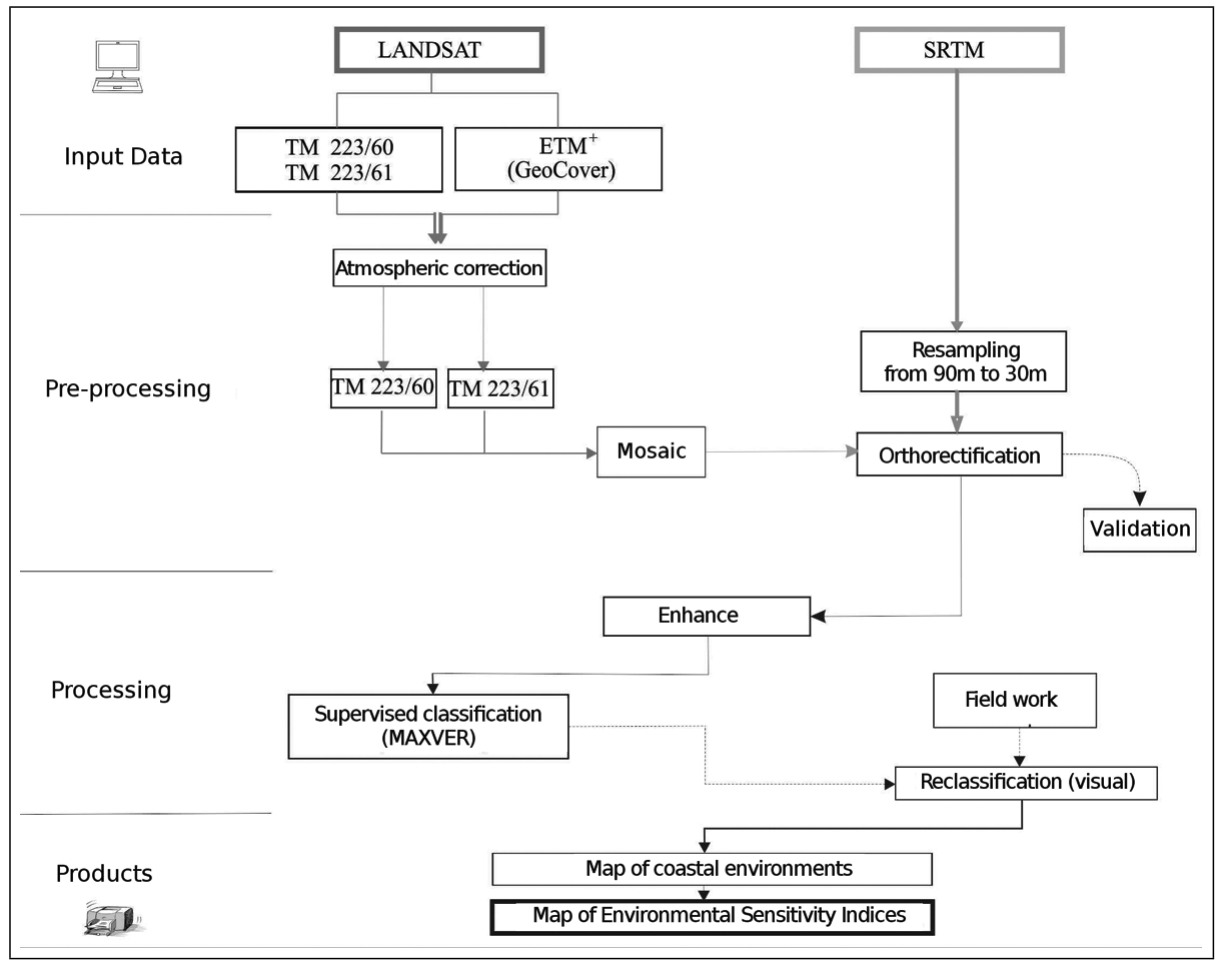

Figure 2 - Flowchart of the methodology used to process the Landsat and SRTM images.

Table 2 - Standard planimetric accuracy and error of the classes $A, B$ and $C$.

\begin{tabular}{|c|c|c|c|}
\hline Class & PEC $(\mathrm{m})$ & $\mathrm{EP}(\mathrm{m})$ & $\sigma_{x}(\mathrm{~m})$ \\
\hline $\mathrm{A}$ & 0.5 & 0.3 & 21.213 \\
$\mathrm{~B}$ & 0.8 & 0.5 & 35.355 \\
$\mathrm{C}$ & 1.0 & 0.6 & 42.426 \\
\hline
\end{tabular}

Table 3 - Formulas to analyze PEC (Camargo et al., 2007).

\begin{tabular}{|l|l|}
\hline $\begin{array}{l}\text { The hypothesis test }<<t>>\text { allows checking } \\
\text { if the average discrepancy is zero. The following } \\
\text { hypotheses are evaluated }\end{array}$ & $\begin{array}{l}H_{0}: \Delta \bar{X}=0 \\
H_{1}: \Delta \bar{X} \neq 0\end{array}$ \\
\hline Confidence interval is calculated by: & $|t x|<t_{(n-1, \alpha / 2)}$ \\
\hline Hypotheses evaluated by the chi-square test & $\begin{array}{l}H_{0}: S_{\Delta X=\sigma^{2} X}^{2} \\
H_{1}: S_{\Delta X>\sigma^{2} X}^{2}\end{array}$ \\
\hline Statistics calculated from the sample variance & $X^{2} x=(n-1) \frac{S_{\Delta X}^{2}}{\sigma_{\Delta X}^{2}}$ \\
\hline $\begin{array}{l}\text { Certify whether the calculated value is within the } \\
\text { null hypothesis acceptance interval }\end{array}$ & $X^{2} x \leq X_{(n-1, \alpha)}^{2}$ \\
\hline \multicolumn{2}{|c|}{ Obs.: If the value is not within the interval, the null hypothesis is rejected, } \\
that is, the chart does not meet the established accuracy
\end{tabular}


After image orthorectification, supervised classification was performed using the MAXVER algorithm, taking as reference the map produced by Rodrigues \& Souza Filho (2011). Thus, it was possible to recognize nine classes representing the following environments: coastal plateau, mangrove, salt and freshwater marsh, dunes, sandy tidal flat, macro-tidal beach, water with and without suspended sediment, due to similar spectral correspondence in several classified environments.

For accurate classification, the kappa index (Cohen, 1960) was calculated. Field surveys were carried out based on a chart generated by previous interpretation of the images. This step was accomplished with ground-truth control point collection using GPS, tracking and field reconnaissance of morphological units.

From the field validation, we identified five new classes as follows: lakes, sandy bars, ebb tide delta, floodplain and paleo- dunes. Therefore, a total of 13 classes were recognized on the field and classified in the satellite images.

After reconnaissance of the environments, these were grouped according to what was proposed by Souza Filho et al. (2009b) for mapping the environmental sensitivity index to oil spills in coastal Amazon region.

\section{RESULTS AND DISCUSSION}

Reconnaissance of coastal environments along the estuary of Rio Curuçá

Thirteen classes were recognized (Fig. 3B and Table 4) as follows: coastal plateau (A), floodplain (B), lakes (C), sandy bars (D), ebb tide delta $(E)$, sandy tidal flat $(F)$, macro-tidal beach $(G)$, exposed dunes $(H)$, mangrove $(I)$, salty marsh $(J)$, freshwater marsh $(K)$, paleodunes (L); and last, the two classes water with and without

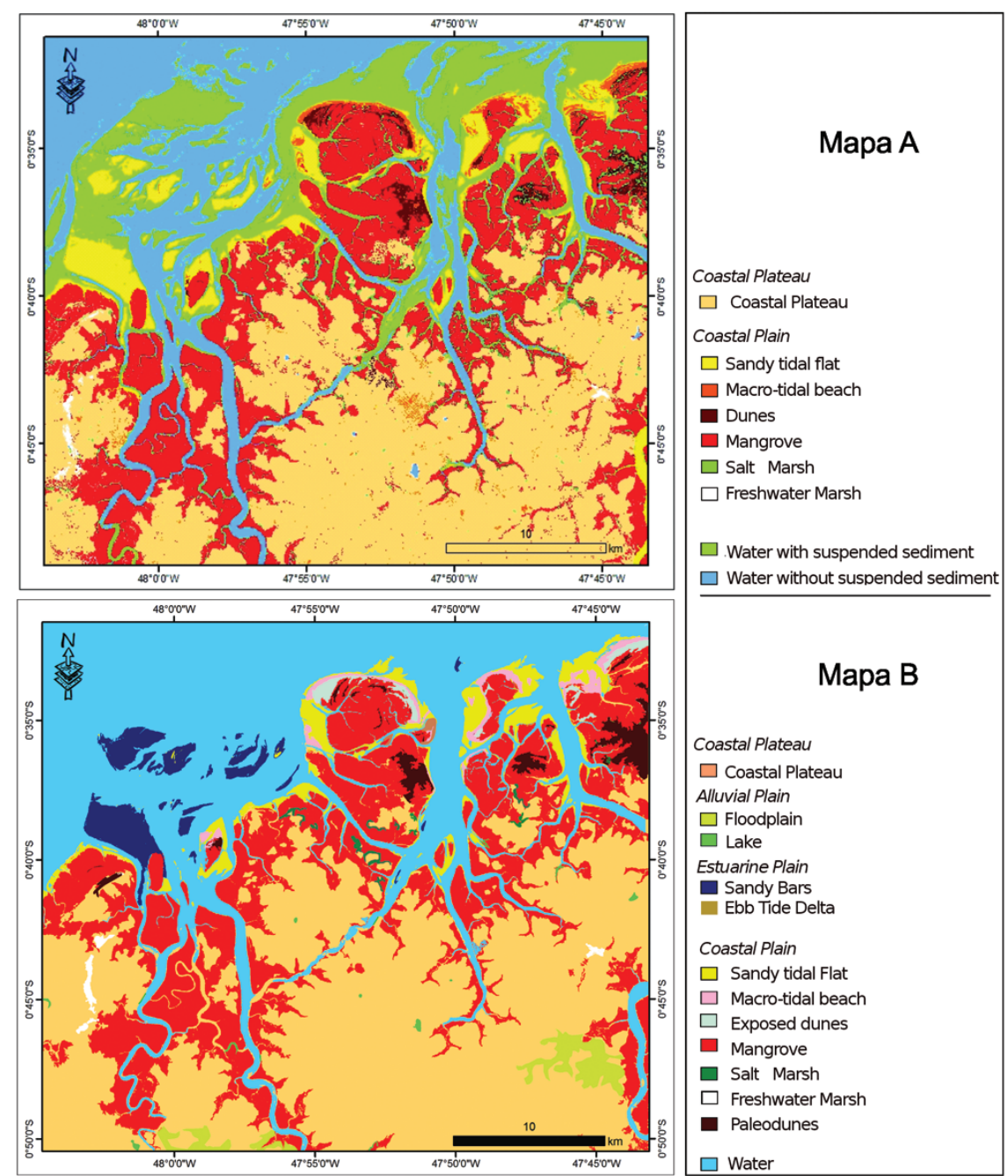

Figure 3 - (A) Supervised rating/classification of the environments (B) reclassification of the environments of Figure 3A. 
Table 4 - Confusion Matrix and kappa index of the classes generated.

\begin{tabular}{|c|c|c|c|c|c|c|c|c|c|c|c|c|c|c|c|c|}
\hline Classes & A & B & C & D & $\mathrm{E}$ & $\mathrm{F}$ & $\mathrm{G}$ & $\mathrm{H}$ & I & $J$ & K & L & $\mathrm{M}$ & Total & $\begin{array}{c}\text { Commission } \\
(\%)\end{array}$ & $\begin{array}{c}\text { User precision } \\
(\%)\end{array}$ \\
\hline $\bar{A}$ & 110 & 0 & 0 & 0 & 0 & 1 & 1 & 0 & 5 & 0 & 0 & 0 & 0 & 117 & 5.98 & 94.02 \\
\hline B & 0 & 3 & 0 & 0 & 0 & 0 & 0 & 0 & 0 & 0 & 0 & 0 & 0 & 3 & 0.00 & 100 \\
\hline C & 0 & 0 & 3 & 0 & 0 & 0 & 0 & 0 & 0 & 0 & 0 & 0 & 0 & 3 & 0.00 & 100 \\
\hline D & 0 & 0 & 0 & 5 & 0 & 2 & 0 & 0 & 0 & 0 & 0 & 0 & 0 & 7 & 28.57 & 71.43 \\
\hline$E$ & 0 & 0 & 0 & 0 & 2 & 0 & 0 & 0 & 0 & 0 & 0 & 0 & 0 & 2 & 0.00 & 100 \\
\hline$F$ & 0 & 0 & 0 & 1 & 1 & 3 & 0 & 0 & 0 & 0 & 0 & 0 & 0 & 5 & 40.00 & 60 \\
\hline G & 10 & 0 & 0 & 0 & 0 & 0 & 9 & 0 & 0 & 0 & 0 & 0 & 0 & 19 & 52.63 & 47.37 \\
\hline $\mathrm{H}$ & 0 & 0 & 0 & 0 & 0 & 0 & 0 & 3 & 0 & 0 & 0 & 0 & 0 & 3 & 0.00 & 100 \\
\hline 1 & 3 & 0 & 0 & 0 & 0 & 0 & 0 & 1 & 65 & 0 & 0 & 0 & 0 & 69 & 5.80 & 94.20 \\
\hline$J$ & 0 & 0 & 0 & 0 & 0 & 0 & 0 & 0 & 0 & 4 & 0 & 0 & 0 & 4 & 0.00 & 100 \\
\hline K & 0 & 0 & 0 & 0 & 0 & 0 & 0 & 0 & 0 & 0 & 2 & 0 & 0 & 2 & 0.00 & 100 \\
\hline L & 0 & 0 & 0 & 0 & 0 & 0 & 0 & 0 & 0 & 0 & 0 & 2 & 0 & 2 & 0.00 & 100 \\
\hline M & 1 & 0 & 0 & 0 & 1 & 1 & 0 & 0 & 1 & 0 & 1 & 0 & 59 & 64 & 7.81 & 92.19 \\
\hline TOTAL & 124 & 3 & 3 & 6 & 4 & 7 & 10 & 4 & 71 & 4 & 3 & 2 & 59 & 300 & & \\
\hline Omission (\%) & 11.29 & 0 & 0 & 16.67 & 50 & 57.14 & 10 & 25 & 8.45 & 0 & 33.33 & 0 & 0 & & & \\
\hline $\begin{array}{c}\text { Producer } \\
\text { accuracy (\%) }\end{array}$ & 88.71 & 100 & 100 & 83.33 & 50 & 42.86 & 90 & 75 & 91.55 & 100 & 66.67 & 100 & 100 & & & \\
\hline
\end{tabular}

$A=$ coastal plateau; $B=$ floodplain $C=$ lake; $D=$ sandy bars; $E=$ ebb tide delta; $F=$ sandy tide flat; $G=$ macro-tide beach; $H=$ exposed dunes; $I=$ mangrove; $\mathrm{J}=$ salt marsh; $\mathrm{K}=$ freshwater marsh; $\mathrm{L}=$ Paleodunes; $\mathrm{M}=$ water.

suspended sediment were grouped into a single water class (M). The Kappa index of 0.86 obtained corresponds to a "very good accuracy" according to the evaluation of Cohen (1960). The overall accuracy rate obtained from the 300 sampling points collected was $90 \%$.

After the equivalent area of each class was determined, the total area was calculated as $1300.8 \mathrm{~km}^{2}$. The areas of the two classes, coastal plateau and floodplain, corresponding to $58.4 \%$ of the studied area, were subtracted from the total area; therefore, the work was restricted to the classes that are susceptible to oil spills and make up for $41.6 \%\left(541.6 \mathrm{~km}^{2}\right)$ of the studied area. Based on this information, we highlight the mangrove $\left(388.4 \mathrm{~km}^{2}\right)$ representing $72 \%$ of the area of the ESI map, in order to call attention to the sensitivity of an area subjected to a possible oil spill.

Of the other classes, corresponding to $28 \%$, the sandy tidal flat 13\% $\left(69.34 \mathrm{~km}^{2}\right)$ and sandy bars $6 \%\left(32.8 \mathrm{~km}^{2}\right)$ areas stand out, followed by classes with smaller areas, such as: macro-tidal beaches $2.8 \%\left(15.6 \mathrm{~km}^{2}\right)$, paleodunes $\left(13.3 \mathrm{~km}^{2}\right)$ and freshwater marsh $\left(9 \mathrm{~km}^{2}\right)$ with $2 \%$ each, exposed dunes $1 \%\left(6.8 \mathrm{~km}^{2}\right)$, ebb tide delta $0.6 \%\left(3 \mathrm{~km}^{2}\right)$, salt marsh $0.4 \%\left(2.12 \mathrm{~km}^{2}\right)$ and lakes $0.2 \%\left(1.2 \mathrm{~km}^{2}\right)$.

Regarding environment classification accuracy, the areas floodplain (B), lake (C), ebb tide delta (E), salt (J) and freshwater marsh $(K)$ displayed commission and omission errors equal to zero, that is, nothing has been commissioned and/or classified as another class, with the exception of class (E), where $50 \%$ of the samples were classified as other classes (sandy tidal flat $\mathrm{F}$ and water $-\mathrm{M}$ ) due to spectral similarity. The mangrove (I) and coastal plateau (A) classes that yielded low commission (5.80 and $5.98 \%$ ) and omission (8.45 and $11.29 \%$, respectively) errors also obtained good ratings, as opposed to the macro-tidal class (G) that commissioned approximately $53 \%$ of its samples to other classes, due to spectral similarity of some collected pixels.

Table 5 shows the classes and the distribution of sampled pixels in the image, identifying how many pixels were commissioned and/or omitted to other classes and how many pixels were correctly classified.

\section{Production of the Environmental Sensitivity Index (ESI) map for Curuçá}

The statistics results based on "t" and $\chi^{2}$ tests validated the postorthorectification planimetric validation (Table 6) to determine the map scale of 1:100,000 class $A$, according to the values established by the Cartographic Accuracy Standards (CAS) at a confidence level of $90 \%$. This result places the ESI map produced in the category of tactical maps, with scale varying from 1:150,000 to $1: 50,000$ according to the MMA. 
Table 5 - Classification and quantification of the coastal systems defined in the study site.

\begin{tabular}{|c|c|c|c|c|c|}
\hline CLASS & $\begin{array}{l}\text { LITHOLOGY I } \\
\text { SEDIMENTS }\end{array}$ & $\begin{array}{c}\text { COLOR } \\
\text { COMPOSITION } \\
453 \text { RGB }\end{array}$ & $\begin{array}{l}\text { GENERAL CLASS } \\
\text { CHARACTERISTICS }\end{array}$ & $\begin{array}{l}\text { AREA } \\
\left(\mathrm{km}^{2}\right)\end{array}$ & $\begin{array}{l}\text { IMAGE } \\
\text { LANDSAT-5 } \\
\text { TM 453 RGB }\end{array}$ \\
\hline $\begin{array}{l}\text { Coastal } \\
\text { Plateau }\end{array}$ & $\begin{array}{l}\text { Sandy-clayey } \\
\text { sediments }\end{array}$ & Reddish orange & $\begin{array}{l}\text { Hills corresponding to the coastal } \\
\text { plain basement }\end{array}$ & 302.02 & \\
\hline \multicolumn{6}{|l|}{$\begin{array}{l}\text { Alluvial } \\
\text { plain }\end{array}$} \\
\hline Floodplain & $\begin{array}{l}\text { Oxidized mud with } \\
\text { remnants of roots and } \\
\text { organic matter }\end{array}$ & Orange brown & $\begin{array}{c}\text { Low flat area, bordered by } \\
\text { marginal dike and the Coastal } \\
\text { Plateau }\end{array}$ & 19.59 & \\
\hline Lakes & $\begin{array}{l}\text { Siliciclastic fine sands } \\
\text { rich in organic matter } \\
\text { and clay }\end{array}$ & $\begin{array}{l}\text { Dark grey to } \\
\text { black }\end{array}$ & $\begin{array}{l}\text { Water bodies associated with the } \\
\text { field of current dunes and } \\
\text { paleodunes, being limited by them }\end{array}$ & 1.2 & \\
\hline \multicolumn{6}{|l|}{$\begin{array}{l}\text { Estuarine } \\
\text { Plain }\end{array}$} \\
\hline $\begin{array}{l}\text { Estuarine } \\
\text { Canal }\end{array}$ & $\begin{array}{l}\text { Intercalated sand and } \\
\text { mud, forming sloping } \\
\text { sandy layers covered } \\
\text { by mud, featuring a } \\
\text { heterolytic stratification }\end{array}$ & Dark blue & Estuarine Canal & - & \\
\hline $\begin{array}{l}\text { Estuarine } \\
\text { Funnel }\end{array}$ & & Dark grey & $\begin{array}{l}\text { Corresponds to the most distal } \\
\text { zone of the estuary, its mouth, } \\
\text { characterized by an opening } \\
\text { toward the Atlantic Ocean, tapering } \\
\text { up toward the mainland. }\end{array}$ & - & \\
\hline $\begin{array}{l}\text { Sandy tidal } \\
\text { bar }\end{array}$ & $\begin{array}{l}\text { Siliciclastic fine sands } \\
\text { with vegetation } \\
\text { fragments and shells }\end{array}$ & Light blue & $\begin{array}{c}\text { Flat and elongated bodies, whose } \\
\text { evidence is associated with tidal } \\
\text { variations }\end{array}$ & 32.8 & \\
\hline $\begin{array}{l}\text { Sinuous } \\
\text { meandering } \\
\text { segment }\end{array}$ & & Black & $\begin{array}{l}\text { Corresponds to the estuarine } \\
\text { sector in which they occur } \\
\text { meanders with } \\
\text { regular sinuosity, forming broad } \\
\text { curves }\end{array}$ & - & \\
\hline $\begin{array}{l}\text { Ebb tide } \\
\text { delta }\end{array}$ & Siliciclastic sands & $\begin{array}{l}\text { Orange and } \\
\text { bluish white }\end{array}$ & $\begin{array}{l}\text { Unfolds in the mouth of estuarine } \\
\text { channels }\end{array}$ & 3 & \\
\hline \multicolumn{6}{|l|}{$\begin{array}{l}\text { Coastal } \\
\text { Plain }\end{array}$} \\
\hline Paleodunes & $\begin{array}{l}\text { Fine and very fine } \\
\text { siliciclastic sands }\end{array}$ & Light green & $\begin{array}{l}\text { Sandy fields that were totally } \\
\text { adulterated and depleted }\end{array}$ & 13.3 & \\
\hline $\begin{array}{l}\text { Exposed } \\
\text { Dunes }\end{array}$ & $\begin{array}{l}\text { Fine and very fine } \\
\text { siliciclastic sands }\end{array}$ & Light green & $\begin{array}{l}\text { Fixed and mobile dunes parallel to } \\
\text { the coastline }\end{array}$ & 6.8 & \\
\hline $\begin{array}{l}\text { Sandy tidal } \\
\text { Flat }\end{array}$ & Fine sands & Bluish white & Correspond to sandy plains & 69.34 & \\
\hline Mangrove & $\begin{array}{l}\text { Mud rich in organic } \\
\text { material }\end{array}$ & Reddish brown & $\begin{array}{c}\text { Plain mudflat / Muddy plain } \\
\text { influenced by tides and estuarine } \\
\text { processes }\end{array}$ & 388.4 & \\
\hline Salt Marsh & $\begin{array}{l}\text { Fields of mud, sand } \\
\text { and salt }\end{array}$ & Greenish grey & $\begin{array}{l}\text { Muddy and sandy plain that is } \\
\text { influenced by tides and estuarine } \\
\text { processes }\end{array}$ & 2.12 & \\
\hline $\begin{array}{l}\text { Freshwater } \\
\text { Marsh }\end{array}$ & $\begin{array}{l}\text { Mud with vegetation } \\
\text { remains and lenses of } \\
\text { organic material }\end{array}$ & Greenish cyan & $\begin{array}{l}\text { Floodplain of waterways or } \\
\text { depressions associated with } \\
\text { oxbow lakes }\end{array}$ & 9 & \\
\hline $\begin{array}{l}\text { Macro-tidal } \\
\text { beach }\end{array}$ & $\begin{array}{l}\text { Fine and very fine } \\
\text { siliciclastic sands }\end{array}$ & White & $\begin{array}{l}\text { Corresponds to areas of strong } \\
\text { tidal influence }\end{array}$ & 15.6 & \\
\hline \multicolumn{4}{|c|}{ TOTAL AREA } & 863.17 & \\
\hline
\end{tabular}


Table 6 - Trend and precision analysis for the 1:100,000 scale of the Curuçá map.

\begin{tabular}{|c|c|c|c|c|c|}
\hline \multicolumn{3}{|c|}{ (A) Trend analysis } & \multicolumn{3}{|c|}{ (B) Precision analysis } \\
\hline$n$ & 40 & points & $n$ & 40 & points \\
\hline$\overline{X_{E}}$ & -1.1331 & m & & & \\
\hline$\overline{X_{N}}$ & -0.0196 & $\mathrm{~m}$ & & & \\
\hline$\overline{S_{E}}$ & 16.1220 & m & $\overline{S_{E}}$ & 16.1220 & m \\
\hline$\overline{S_{N}}$ & 9.5077 & $\mathrm{~m}$ & $\overline{S_{N}}$ & 9.5077 & $\mathrm{~m}$ \\
\hline$E P_{1: 100,000}$ & 30 & $\mathrm{~m}$ & & & \\
\hline$\sigma_{x}$ & 21.2132 & & $\sigma_{x}$ & 21.2132 & $\mathrm{~m}$ \\
\hline$t_{39 ; 0,05}$ & 1.684875122 & & $\chi_{39,10 \%}^{2}$ & 50.6598 & \\
\hline$t_{E}$ & -0.4445 & & $\chi_{E\left(\text { class }_{-} A\right)}^{2}$ & 22.5262 & True \\
\hline$t_{N}$ & -0.0131 & & $\chi_{N\left(\text { class_A }_{-}\right)}^{2}$ & 7.8343 & True \\
\hline Analysis & $\begin{array}{l}\left|t_{E}\right|<t_{\text {amostral }} \\
\left|t_{N}\right|<t_{\text {amostral }}\end{array}$ & & Analysis & $\chi^{2}($ Class & $<\chi_{39,10 \%}^{2}$ \\
\hline Component & & & & Used scale & \\
\hline$E$ & $\begin{array}{l}\text { Without } \\
\text { trend }\end{array}$ & True & & 1:100,000 & \\
\hline N & $\begin{array}{l}\text { With } \\
\text { trend }\end{array}$ & True & & & \\
\hline
\end{tabular}

Legend: $n$ : collected points (samples); $\Delta \bar{X}$ : represents mean discrepancy; $S_{\Delta X}$ : sample standard deviation; $|t x|<t_{(\text {amostral })}$ : confidence interval; $\sigma_{x}$ : standard deviation (EP); $\chi^{2} x \leq \chi^{2}(n-1 \alpha)$ : acceptance interval and confidence level.

Eight environmental sensitivity indices were recognized and mapped in the studied area (Table 7), as presented in Figure 4. The photographs relevant to each index can be seen in Figure 5.

Table 7 - ESI mapped in the study site and the respective coastal environments.

\begin{tabular}{|c|c|}
\hline $\begin{array}{c}\text { Environmental } \\
\text { sensitivity index }\end{array}$ & Units \\
\hline ISA 1B & Retaining wall \\
ISA 1C & Active cliffs \\
ISA 3A & Sandy beaches and exposed dunes \\
ISA 7 & Sandy tidal flat \\
ISA 9 & Ebb tide delta \\
ISA 10A & Salt marsh \\
ISA 10B & Freshwater marsh \\
ISA 10C & Mangrove \\
\hline
\end{tabular}

From the determined indices, the ISA-10C, 10B and 10A are highlighted. The ISA-10C represents $72 \%$ of the generated map and covers the entire coast of the city of Curuçá, especially the Romana islands. In this area, studies have been conducted to evaluate the possibility of leasing an off-shore port for primarily transportation of iron ore.

\section{CONCLUSIONS}

The satellite data processing provided good results/data to be used for the generation of the environmental sensitivity index (ESI) map. This map should be used to support contingency plans in order to reduce the possible impact caused by oil spills and its derivatives in the studied area.

The evaluation according to the Cartographic Accuracy Standard classified the produced map as class A, in scale 1:100,000. This meets the guidelines of the Ministry of Environment for the production of Charts of environmental sensitivity index to oil spills (ESI Chart). Thus, it is possible to generate more accurate ESI charts faster and at lower cost.

Therefore, the use of moderate resolution optical sensors allow to analyze the integrated spatial relationships, enabling re- 


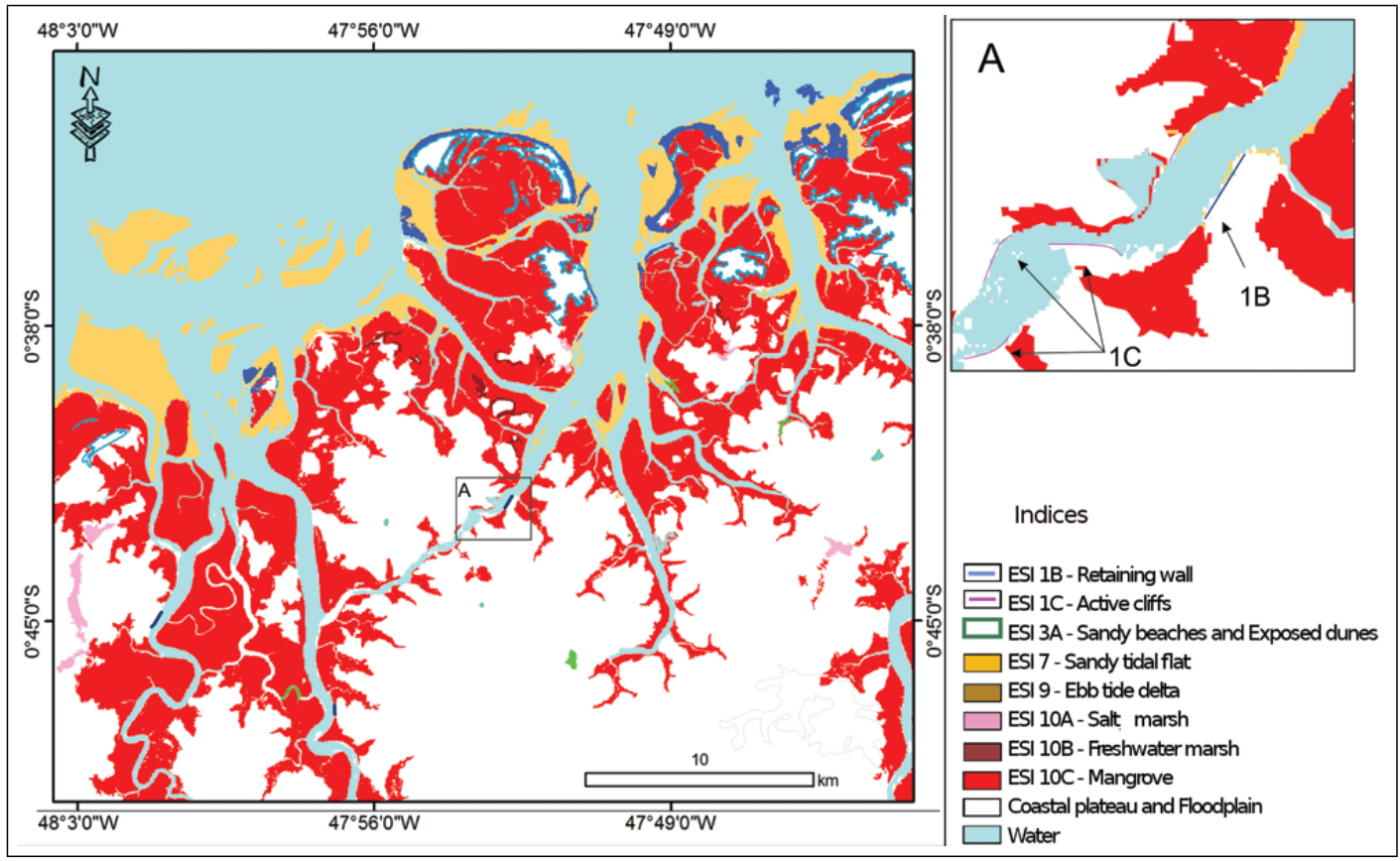

Figure 4 - Map of environmental sensitivity index to oil spills in Curuçá, zoom in the dotted area highlights the ISA's 1B and 1C.
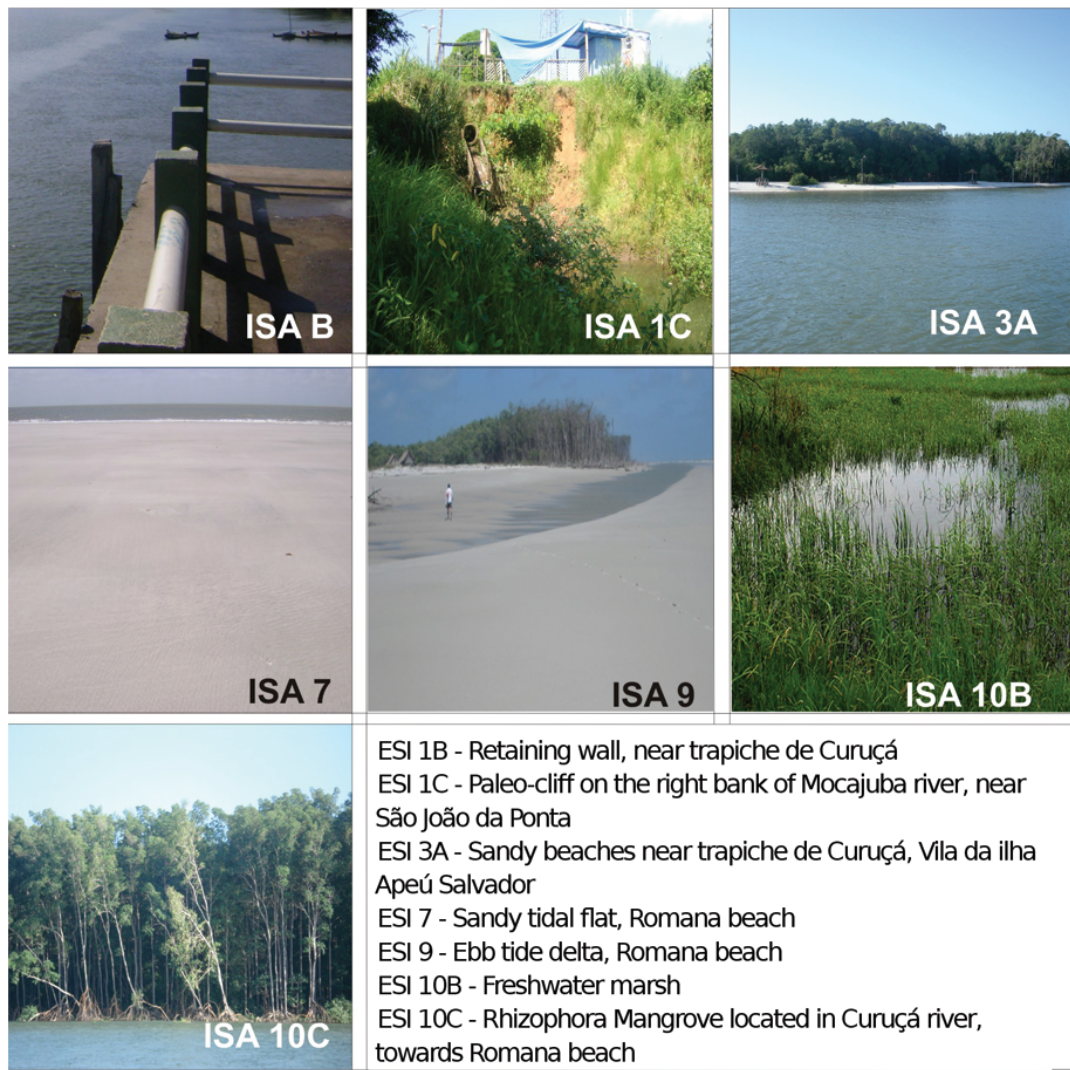

ESI 1B - Retaining wall, near trapiche de Curuçá

ESI 1C - Paleo-cliff on the right bank of Mocajuba river, near São João da Ponta

ESI 3A - Sandy beaches near trapiche de Curuçá, Vila da ilha Apeú Salvador

ESI 7 - Sandy tidal flat, Romana beach

ESI 9 - Ebb tide delta, Romana beach

ESI 10B - Freshwater marsh

ESI 10C - Rhizophora Mangrove located in Curuçá river, towards Romana beach

Figure 5 - Photographs of ESI related environments of Curuçá 
connaissance of the environments and its mapping for various purposes, in addition to supplying high quality cartographic products. A fact that, along with management and prevention plans contributes to the reduction of the impact caused by possible spills of oil and its derivatives.

\section{ACKNOWLEDGMENTS}

The authors thank the Conselho Nacional de Desenvolvimento Científico e Tecnológico (CNPq) for the research grants during this study and CAPES for granting financial aid according to Edital Ciências do Mar.

\section{REFERENCES}

ALCÂNTARA EH \& SANTOS MCFV. 2005. Mapeamento de Áreas de Sensibilidade Ambiental ao Derrame de Óleo na Região Portuária do Itaquí, São Luís, MA-Brasil. Anais XII Simpósio Brasileiro de Sensoriamento Remoto, Goiânia, Brasil, 16-21 abril 2005, INPE, p. 3605-3617.

ALMEIDA EF. 2009. Uso de Dados Multisensor para geração de Cartas de Sensibilidade Ambiental a Derramamentos de Óleo, nos Ecossistemas Costeiros da Região do Cabo Norte, Amapá. Anais XIV Simpósio Brasileiro de Sensoriamento Remoto, Natal, Brasil, 25-30 abril 2009, INPE, p. 4543-4551.

BELLOTTO VR \& SAROLLI VMM. 2008. Environmental sensitivity mapping to oil spill and response actions for shoreline and portuary zone of Imbituba, SC, Brazil. Braz. J. Aquat. Sci. Technol., 12(2): 115-125. ISSN 1808-7035.

BOULHOSA MBM \& SOUZA FILHO PWM. 2009. Reconhecimento e mapeamento dos ambientes costeiros para geração de mapas de ISA ao derramamento de óleo, Amazônia Oriental. Revista Brasileira de Geofísica, 27(Supl. 1): 23-37.

CAMARGO FF, OLIVEIRA CG de, FLORENZANO TG \& ALMEIDA CM de. 2007. Avaliação da acurácia posicional da base cartográfica do município de São José dos Campos (SP) por análises de tendência e precisão. In: XXIII Congresso Brasileiro de Cartografia - I Congresso Brasileiro de Geoprocessamento, 2007, Rio de Janeiro/RJ. Anais... Rio de Janeiro/RJ: SBC, 2007. Artigos, p. 775-780.

CARMONA SL, GHERARDI DFM \& TESSLER MG. 2006. Environmental sensitivity mapping and vulnerability modeling for oil spill response along the São Paulo coastline. Journal of Coastal Research, SI39: 14551458.

CARVALHO M \& GHERARDI DFM. 2008. Mapping the environmental sensitivity to oil spill and land use/land cover using, spectrally transformed Landsat-7 ETM data. Braz. J. Aquat. Sci. Technol., 12(2): 1-9. ISSN 1808-7035.

CASTRO AF, AMARO VE \& VITAL H. 2003. Desenvolvimento de um banco de dados geográficos em um ambiente SIG e sua aplicação na elaboração de mapas de sensibilidade ambiental ao derramamento de óleo em áreas costeiras do estado do Rio Grande do Norte. Anais XI SBSR, Belo Horizonte, Brasil, 05-10 abril 2003, INPE, p. 1533-1540.

CHAVEZ P Jr. 1996. Image-based atmospheric corrections-revisited and improved. Photogrammetric Engineering and Remote Sensing, 62 1025-1036.

COHEN J. 1960. A coefficient of agreement for nominal scales. Educ. Psych. Meas, 20: 37-46.

CPTEC/INPE. Centro de Previsão de Tempo e Estudos Climáticos. 2005. Dados previsionais. Portal oceânico. Available on:

<http://tucupi.cptec.Inpe.br/wam>. Access on: Jan. 5, 2006.

EL ROBRINI M \& MÁCOLA G. 2004. "Ilha dos guarás (Marinteua) município de Curuçá (NE do Pará): aspectos físicos, meteorológicos e oceanográficos". Relatório Final, Companhia docas do Pará. Available on: <http://www.cdp.com.br/images/espadarte/espadarte_estudo_iguras.pdf> Access on: March 6, 2009

GHERARDI DFM, CABRAL AP, KLEIN AHF, MUEHE DCEH, NOERNBERG MA, TESSLER MG \& SARTOR SM. 2008. Mapeamento da sensibilidade ambiental ao óleo da bacia marítima de Santos. Brazilian Journal of Aquatic Science Technology, 12(2): 11-31.

GONCALVES FD, SOUZA FILHO PWM, PARADELLA WR \& MIRANDA FP. 2009. Fusão de dados multisensor para a identificação e o mapeamento de ambientes flúvio-estuarinos da Amazônia. Revista Brasileira de Geofísica, 27(Supl.1): 57-67.

GUNDLACH ER \& HAYES MO. 1978. Vulnerability of coastal environments to oil spill impacts. Journal of Marine Technology Society, 12(4): 18-27.

HALLS J, MICHEL J, ZENGEL S \& PETERSEN J. 1997. Environmental sensitivity index guidelines. Version 2.0, Seattle: Hazardous Materials Response and Assessment Division, National Oceanic and Atmospheric Administration, 79 p. (NOAA Technical Memorandum NOS ORCA 115).

HAYES MO \& GUNDLACH ER. 1975. Coastal geomorphology and sedimentation of the Metula oil spill site in the Straits of Magellan. Report to Advanced Environmental Research Technology, NSF. 103 p.

MINISTÉRIO DO MEIO AMBIENTE - MMA. 2004. Especificações e normas técnicas para elaboração de cartas de sensibilidade ambiental para derramamento de óleo - Cartas SAO, SQAAH, MMA, Brasília, 107 p.

MOE KA, SKEIE GM, BRUDE OW, LOYAS SM, NEDREBO M \& WESLAWISKI JM. 2000. The Svalbard intertidal zone: a concept for the use of GIS in applied oil sensitivity, vulnerability and impact analyses. Spill Science \& Technology Bulletin, 6: 187-206.

NOERNBERG MA, ANGELOTTI R, CALDEIRA GA \& RIBEIRO DE SOUSA AF. 2008. Environmental sensitivity assessment of Paraná coast for oil spill. Braz. J. Aquat. Sci. Technol., 12(2): 49-59. ISSN 1808-7035. 
NOAA. National Oceanic and Atmospheric Administration. PETERSEN J, MICHEL J, ZENGEL S, WHITE M, LORD C \& PLANK C. 2002. Environmental sensitivity index guidelines, Version 3.0. Seattle. NOAA Technical Memorandum NOS OR\&A 11, $89 p$.

PCI Geomatics Enterprises Inc. 2010. EASI/PACE user's manual, version 10.3. PCI Geomatics Enterprises Inc., Richmond Hill, Ont. 165 p.

PETROBRAS - Petróleo Brasileiro S.A. 2002. Manual Básico para Elaboração de Mapas de Sensibilidade Ambiental a Derrames de Óleo no Sistema Petrobras: Ambientes Costeiros e Estuarinos. Rio de Janeiro, $134 \mathrm{p}$.

RODRIGUES SW P \& SOUZA-FILHO PWM. 2011. Índice de sensibilidade ambiental (ISA) a partir do processamento de imagens Landsat TM para o nordeste do Pará (Curuçá - PA, Brasil). Anais XV Simpósio Brasileiro de Sensoriamento Remoto - SBSR, Curitiba, PR, Brasil, INPE, p. 5070.

SANTOS DPD \& GRIEP G. 2007. Mapa de sensibilidade ambiental para derrames de óleo na porção sul de Santa Catarina: uma aplicação para o manejo e conservação de aves e peixes. $4^{\circ}$ IV PDPETRO, Campinas, SP. v. 6.2. p. $0177-1$
SOUZA FILHO PWM, GONÇALVES FD, RODRIGUES SWP, COSTA FR \& MIRANDA FP. 2009a. Multi-sensor data fusion for geomorphological and environmental.sensitivity index mapping in the Amazonian mangrove coast, Brazil. Journal of Coastal Research, 56: 1592-1596.

SOUZA FILHO PWM, PROST MTRDC, MIRANDA FP, SALES MEC, BORGES HV, COSTA FR, ALMEIDA EF \& NASCIMENTO JUNIOR WR. 2009b. Environmental sensitivity index (ESI) Mapping of oil spill in the amazon coastal zone: the PIATAM Mar project. Revista Brasileira de Geofísica, 27(Supl.1): 7-22.

THOMPSON GB \& McENALLY JM. 1985. Coastal Resource Atlas for Oil Spills in Port Jackson. Australian State Pollution Control Commission. Sydney, $27 \mathrm{p}$.

WIECZOREK A \& DIAS-BRITO D, MILANELLI JC. 2007. Mapping oil spill environmental sensitivity in Cardoso Island State Park and surroundings areas, São Paulo, Brazil. Ocean \& Coastal Management, 50(11): 872886.

\section{NOTES ABOUT THE AUTHORS}

Suzan Waleska Pequeno Rodrigues. Graduated in Geology from the Universidade Federal do Pará (2006), specialized in Geotechnology: Remote Sensing and Geoprocessing from the Instituto de Estudos Superiores da Amazônia (2011) and received a master's degree in Geology from the Universidade Federal do Pará (2008). Currently, is a doctoral student in Geology, subarea Marine Geology from UFPA.

Pedro Walfir Martins e Souza Filho. Graduated in Geology from the Universidade Federal do Pará (1993), specialized in Geology and Marine Geology from the Universidade Federal Fluminense (1993), and received master's and doctoral degree in Geology in the area of Remote Sensing of the Universidade Federal do Pará (2000). Currently, holds the position of Associate Professor in the Faculdade de Oceanografia of the Instituto de Geociências da Universidade Federal do Pará since 2002 and Associate Researcher at the Instituto Tecnológico Vale - Sustainable Development. Has a Productivity Research Grant from CNPq since 2003 and Affiliate Member of the Academia Brasileira de Ciências since 2008. 